\title{
Utilización de una ceniza volante de alto contenido en cal en el hormigón y su comportamiento frente a curados acelerados
}

\section{The use of a non-standard high calcium fly ash in concrete and its response to accelerated curing}

CENGIZ D. ATIS", CAHIT BILIM*", FATIH OZCAN", KUBILAY AKCAOZOGLU*, UMUR K. SEVIM*

("The University of Cukurova, Civil Engineering Dept. 01330 Balcali-Adana

(“)Mustafa Kemal University, Civil Engineering Dept. Iskenderun-Hatay

Fecha de recepción: 24-I-02

Fecha de aceptación: 8-IV-02

TURQUíA

\section{RESUMEN}

Se llevó a cabo un trabajo experimental para investigar el uso de una ceniza volante de alto contenido en cal en el hormigón, la cual no cumple las especificaciones recogidas en norma. También, se estudió el comportamiento de la ceniza bajo un curado acelerado. Se elaboraron un total de 48 hormigones con tres proporciones diferentes de material cementante. Las relaciones agua/cemento $(\mathrm{a} / \mathrm{c})$ usadas estaban comprendidas entre 0,40 y 0,87. A 28 días y 3 meses de curado, se determinaron las resistencias a compresión de probetas cúbicas de hormigón elaboradas con 0\%, 15\%, 30\% y 45\% de sustitución de cemento portland por ceniza. También, se determinaron las resistencias a compresión de las probetas de hormigón sometidas a curados acelerados: agua caliente y agua hirviendo, de acuerdo con las normas ASTM y Turcas.

A pesar del hecho que la ceniza volante usada no cumple con la normativa vigente, los resultados de los ensayos de laboratorio mostraron que pueden utilizarse en la producción de hormigón, con un porcentaje de sustitución entre $15 \% y$ $30 \%$ en peso, ya que el hormigón con ceniza desarrolló resistencia a compresión similares o superiores al hormigón de referencia. Los resultados de laboratorio también indicaron que los ensayos acelerados pueden usarse para predecir la resistencia a compresión de hormigón con ceniza, con un coeficiente de correlación del 85\%. La proporción de ceniza no influye en la predicción de resistencia. La relación encontrada para las resistencias a compresión entre el método de agua caliente y el método de agua hirviendo tiene una forma lineal, con un coeficiente de correlación del $93 \%$.

\section{SUMMARY}

An experimental work was carried out to investigate the use of a non-standard high calcium fly ash in concrete. The response of the same fly ash to the accelerated curing was also explored. With three different cementitious material contents, a total of 48 concretes were produced. The water/ cement ratios were varied from 0.40 to 0.87 . Compressive strengths of the moist cured cube specimens cast from the concrete mixtures made with $0 \%, 15 \%, 30 \%$ and $45 \%$ replacement of normal Portland cement with fly ash were measured at 28 days and 3 months. Accelerated compressive strengths were also measured using warmwater method and boiling-water method in accordance with the relevant ASTM and Turkish Standards.

Despite the fact that the fly ash used was a non-standard, the laboratory test results showed that it could be utilized in concrete production at a replacement level between $15 \%$ and $30 \%$ by weight basis because fly ash concrete developed comparable or higher compressive strength than that of corresponding normal Portland cement concrete. The laboratory test results also indicated that the accelerated curing could be used to predict the compressive strength of fly ash concrete with $85 \%$ correlation coefficient. The amount of fly ash was found to be immaterial in the strength prediction. The relation between warm-water method and boiling-water method was of linear form with 93\% correlation coefficient.
PALABRAS CLAVE: ceniza volante de alto contenido en cal, resistencia a compresión, curado acelerado
KEYWORDS: high calcium fly ash, strength, accelerated curing 


\section{INTRODUCCIÓN}

El uso de ceniza volante en el hormigón se utiliza a nivel mundial ya que modifica las propiedades del hormigón en estado fresco y endurecido y, por otro lado, por su repercusión económica y medioambiental, porque la ceniza es un subproducto industrial procedente de las centrales termoeléctricas, las cuales utilizan carbón como combustible (1-4). Las propiedades físicas y composición química de la ceniza volante varían dependiendo del tipo de carbón y de la central termoeléctrica, por lo que éstas pueden variar diariamente (5). Las cenizas volantes se clasifican por su contenido en cal (6). Si el contenido en cal ( $\mathrm{CaO})$ es menor al $10 \%$ se clasifica como cv baja en cal o clase $\mathrm{F}$ (7). Si el contenido en cal es mayor al $10 \%$, las cenizas se clasifican de alto contenido en cal o clase C (7). El uso de ceniza volante según sus propiedades fisicas y composición química está recogido en diferentes normas. Así, el ASTM (7) limita la cantidad mínima de $\mathrm{SiO}_{2}+\mathrm{Al}_{2} \mathrm{O}_{3}+\mathrm{Fe}_{2} \mathrm{O}_{3}$ a $50 \%$ para las cenizas altas en cal y de un $70 \%$ para las cenizas bajas en cal.

Por otro lado, las cenizas que no cumplen los requerimientos establecidos en las normas, han sido estudiadas en trabajos previos, llevados a cabo por Atis (8) y Zhang et al. (9) poniendo de manifiesto que este tipo de cenizas podían usarse en hormigones, atendiendo a sus resistencias a compresión.

El objetivo de este trabajo fue investigar el uso de una ceniza local "Afsin-Elbistan" en el hormigón. Es una ceniza con un alto contenido en cal que no cumple con las normas vigentes sobre la incorporación cenizas volantes en el hormigón. Tokyay y Erdogdu (10) la clasificaron como una ceniza de alta en cal y sulfato. La investigación se llevó a cabo atendiendo a la resistencia a compresión. También, se investigó la respuesta de esta ceniza a diferentes curados acelerados con el objetivo de predecir la resistencia a compresión a edades tempranas de curado.

\section{PROGRAMA EXPERIMENTAL}

\section{Materiales usados en la investigación}

\section{Cemento}

Aunque, la ceniza usada no cumple con todos Se usó un cemento Portland (PC 42,5 N/mm²) que cumple con las especificaciones recogidas en la norma TSI (11). La densidad del cemento era de $3,16 \mathrm{~g} / \mathrm{cm}^{3}$. Los tiempos de fraguado iniciales y finales fueron 3 horas y 20 minutos y, 4 horas y 10 minutos, respectivamente. La superficie específica "Blaine" era $3.140 \mathrm{~cm}^{2} / \mathrm{g}$ y el porcentaje de retenido en los tamices de 200 y 900 fue de $0 \%$ y $0,4 \%$ respectivamente. Su composición química se presenta en la Tabla 1.

\section{INTRODUCTION}

Using fly ash in concrete is accepted widely in the world due to the fact that it modifies the properties of the concrete in both fresh and hardened state. The use of fly ash in concrete is also ecomomic and friendly to the environment, because fly ash is a by-product or a waste of the coal combustion power station (1-4). The physical properties and chemical composition of fly ash change due to the type of coal and the factory where the coal was burned. The daily changes in the physical property and chemical composition can also be seen for a specific ash (5). Fly ashes classified as high calcium and low calcium fly ashes according to its $\mathrm{CaO}$ content (6). If the $\mathrm{CaO}$ content is less than $10 \%$ then the ash classified as low calcium or class $F$ (7). If the $\mathrm{CaO}$ content is more than $10 \%$ then the ash classified as high calcium or class $C$ (7). The use of fly ash according to its physical property and chemical composion are picked up in different standards. So, the ASTM (7) restricts the amount of $\mathrm{SiO}_{2}+\mathrm{Al}_{2} \mathrm{O}_{3}+\mathrm{Fe}_{2} \mathrm{O}_{3}$ to $=50 \%$ for high calcium fly ash and $=70 \%$ for low calcium fly ash.

It was shown that a non-standard fly ash can also be used in concrete, for example Atis (8) has shown that Aberthaw fly ash did not conform the relevant standard however, it provided excellent strength gain. Zhang et al.(9) also showed that a non standard fly ash could also be used in concrete.

The aim of this work was to investigate the use of a local Afsin-Elbistan fly ash in the elaboration of blended concrete. It was a non-standard and high calcium fly ash. Tokyay and Erdoðdu (10) classified it as high sulfate and high calcium fly ash. The investigation was made on the basis of compressive strength. The response of the same fly ash to the accelerated curing was also investigated for early strength prediction as a part of this work.

\section{EXPERIMENTAL PROGRAM}

\section{Materials used in the investigation}

\section{Cement}

The cement used was normal Portland cement (PC $42.5 \mathrm{~N} / \mathrm{mm}^{2}$ ) which conforms to the currrent specifications as described in TSI (11). Specific gravity of the cement used was $3.16 \mathrm{~g} / \mathrm{cm}^{3}$. Initial and final setting times of the cement were 3 hours and 20 minutes and, 4 hours and 10 minutes respectively. Its Blaine specific surface area was $3140 \mathrm{~cm}^{2} / \mathrm{g}$. The remaining of the cement on 200 and 90-microns sieve were $0 \%$ and $0.4 \%$ respectively. Its chemical composition is given in Table 1. 


\section{Ceniza volante}

La ceniza volante usada se obtuvo de la central térmica "Afsin-Elbistan" en Turquía,. Es una ceniza con alto contenido en cal $(\mathrm{CaO}>10 \%)$ y en sulfato $(7,10)$. Su composición química se presenta en la Tabla 1 . Su densidad era de $2,70 \mathrm{~g} / \mathrm{cm}^{3}$ y con una superficie específica "Blaine" de $2.900 \mathrm{~cm}^{2} / \mathrm{g}$. El retenido de ceniza en el tamiz de 45 micras fue del $14 \%$.

Algunas especificaciones recogidas (ASTM (7), BSI1 (2), TSI (13), EN (14)) se presentan en Tabla 2. En ella, puede verse que el contenido de $\mathrm{SO}_{3}$ para las cenizas volantes está limitado entre $2,5 \%$ y $5 \%$. La ceniza analizada presenta unos contenidos de $\mathrm{SO}_{3}$ del $12,06 \%$, por lo que esta ceniza volante no cumple con las especificaciones recogidas en las normas

\section{Fly ash}

The fly ash used was obtained from the electricity generating Afsin-Elbistan Thermal Power Station in Turkey. It is a high calcium ( $\mathrm{CaO}>10 \%)$ and high sulfate fly ash $(7,10)$. Its chemical composition is given in Table 1. Its specific gravity was $2.70 \mathrm{gr} / \mathrm{cm}^{3}$ and Blaine specific surface area was $2900 \mathrm{~cm}^{2} / \mathrm{gr}$. Remaining of fly ash on the 45 rm sieve was $14 \%$.

Some standard specifications (ASTM (7), BSI (12), TSI (13), EN (14)) are given in Table 2. It can be seen from Table 2 that $\mathrm{SO}_{3}$ content of fly ash restricted between $2.5 \%$ and $5 \%$. The fly ash used does not not comply with any of the standard $(7,12-14)$, because its $\mathrm{SO}_{3}$ content is $12.06 \%$. The total alkali contents $\left(\mathrm{Na}_{2} \mathrm{O}+\mathrm{K}_{2} \mathrm{O}=1.83 \%\right)$ does not comply with $\mathrm{ASTM}^{7}$

TABLA $1 / T A B L E 1$

Composición química del cemento y la ceniza volante (\%)

(Chemical composition of cement and fly ash (\%))

\begin{tabular}{|l|l|l|l|l|l|l|l|l|l|}
\hline $\begin{array}{l}\text { Composicion } \\
\text { (Composition) }\end{array}$ & $\mathrm{SiO}_{2}$ & $\mathrm{Al}_{2} \mathrm{O}_{3}$ & $\mathrm{Fe}_{2} \mathrm{O}_{3}$ & $\mathrm{CaO}$ & $\mathrm{MgO}$ & $\mathrm{SO}_{3}$ & $\mathrm{Na}_{2} \mathrm{O}$ & $\mathrm{K}_{2} \mathrm{O}$ & LOI \\
\hline $\begin{array}{l}\text { Cemento } \\
\text { (Cement) }\end{array}$ & 20.65 & 5.60 & 4.13 & 61.87 & 2.60 & 2.79 & 0.14 & 0.83 & 0.5 \\
\hline $\begin{array}{l}\text { Ceniza Volante } \\
\text { (Fly ash) }\end{array}$ & 18.95 & 7.53 & 3.82 & 51.29 & 1.58 & 12.06 & 0.32 & 1.51 & 2.94 \\
\hline
\end{tabular}

TABLA 2/TABLE 2

Límites normalizados para la composición química y las propiedades fisicas de ceniza volante (Limits of standards for chemical composition and physical properties of fly ash)

\begin{tabular}{|c|c|c|c|c|c|}
\hline & $\mathrm{BSI}^{12}$ & $\begin{array}{l}\text { ASTM }^{7} \\
\text { Class F }\end{array}$ & $\begin{array}{l}\text { A STM }^{7} \\
\text { Class C }\end{array}$ & $\mathrm{EN}^{14}$ & $\mathrm{TSI}^{13}$ \\
\hline Humedad (máx) (Max. Moisture) & 0.5 & 3 & 3 & - & - \\
\hline $\begin{array}{l}\text { Pérdida por calcinación (máx.) } \\
(\text { Max. LOI) }\end{array}$ & 7.0 & 12 & 6 & 5.0 & 5.0 \\
\hline $\begin{array}{c}\text { Contenido de } \mathrm{SO}_{3}(\mathrm{máx}) \\
\left(\mathrm{Max} \mathrm{SO}_{3}\right)\end{array}$ & 2.5 & 5 & 5 & 3.0 & 3.0 \\
\hline $\begin{array}{c}\text { Contenido de } \mathrm{MgO} \text { (máx) } \\
(M \operatorname{ax} M g O)\end{array}$ & 4.0 & 5 & 5 & - & - \\
\hline $\begin{array}{c}\text { Contenido de álcalis (máx) } \\
\text { (Max álcali) }\end{array}$ & - & 1.5 & 1.5 & - & - \\
\hline $\begin{array}{c}\text { Contenido de } \mathrm{SiO}_{2}(\mathrm{~min}) \\
\left(\mathrm{Min} \mathrm{SiO}_{2}\right)\end{array}$ & - & - & 40 & - & - \\
\hline $\mathrm{Al}_{2} \mathrm{O}_{3}$ & - & - & - & - & - \\
\hline $\mathrm{Fe}_{2} \mathrm{O}_{3}$ & - & - & - & - & - \\
\hline $\mathrm{SiO}_{2}+\mathrm{Al}_{2} \mathrm{O}_{3}+\mathrm{Fe}_{2} \mathrm{O}_{3}(\mathrm{~min})$ & - & 70 & 50 & - & - \\
\hline $\begin{array}{l}\text { Cal libre (máx) } \\
\text { (Max free lime) }\end{array}$ & - & - & - & $1.0-2.5$ & $1.0-2.5$ \\
\hline C1\%(máx) & - & - & - & 0.1 & 0.1 \\
\hline $\begin{array}{c}\text { Índice actividad Puzolánica \% } \\
(\text { minimo }) \\
(P A I \text { min })\end{array}$ & - & 75 & 75 & $\begin{array}{l}75 \% \text { en } 28 \text { dias } \\
(75 \% \text { at } 28 \text { days }) \\
85 \% \text { en } 90 \text { dias } \\
(85 \% \text { at } 90 \text { days }) \\
\end{array}$ & $\begin{array}{l}75 \% \text { en } 28 \text { dias } \\
(75 \% \text { at } 28 \text { days }) \\
85 \% \text { en } 90 \text { dias } \\
(85 \% \text { at } 90 \text { days })\end{array}$ \\
\hline $\begin{array}{c}\text { Finura }(\%) \text { (retenido máximo en tamiz } \\
\text { de } 45 \mu \mathrm{m}) \\
\text { (Max fineness }(\%)) \\
\text { (remanining on } 45 \mu \mathrm{m} \text { size sieve) }\end{array}$ & 12.5 & 34 & 34 & 40 & 40 \\
\hline $\begin{array}{l}\text { Expansión (máx) } \\
\text { (Max expansion) }\end{array}$ & - & - & - & $10 \mathrm{~m} \mathrm{~m}$ & $10 \mathrm{~m} \mathrm{~m}$ \\
\hline
\end{tabular}


mencionadas anteriormente $(7,12,13,14) . \mathrm{Su}$ contenido total de álcalis $\left(\mathrm{Na}_{2} \mathrm{O}+\mathrm{K}_{2} \mathrm{O}=1,83 \%\right)$ tampoco cumple con la norma ASTM $(7)(<1,5 \%)$ y la misma situación corresponde con el contenido de $\mathrm{SiO}_{2}(18,95 \%)$, valor muy bajo para volantes de clase C, cuya norma ASTM (7) exige como mínimo un $40 \%$ para este tipo de cenizas volantes. El contenido total de $\mathrm{SiO}_{2}+\mathrm{Al}_{2} \mathrm{O}_{3}+\mathrm{Fe}_{2} \mathrm{O}_{3}$ de la ceniza empleada era aproximadamente del $30 \%$, valor excluido de la norma ASTM (mínimo 50\%). Aunque la ceniza usada no cumple con todos los requisitos establecidos en las diferentes normas, sin embargo, la ceniza usada cumple con otros requisitos normativos, como, por ejemplo, la finura, cuyo retenido en el tamiz de 45 micras fue del 14\%, menor del $40 \%$ limitado por las normas TSI (13) y EN (14), y menor del $34 \%$ de la ASTM (7). Sin embargo, no cumple con la norma BSI12 (máximo $12,5 \%)$. Con respecto a la pérdida por calcinación, estaría dentro de las limitaciones recogidas en dichas normas $(7,12,13,14)$. El índice de actividad puzolánica (IAP) de la ceniza a 28 días y 90 días fue del $84 \%$ y $92 \%$, respectivamente. Este IAP cumple con la norma TSI (13) y EN (14), las cuales limitan este límite al $75 \%$ y $85 \%$ para los 28 días y 90 días de curado. Los contenidos de cal libre de la ceniza no cumplirían con lo establecido en las normas TSI (13) y EN (14), porque su contenido alcanza el 3\%. Tampoco, el resultado de expansión $(41 \mathrm{~mm}$ ) cumpliría con lo establecido en las normas TSI (13) y EN (14) (ver Tabla 2).

\section{Áridos}

La arena y la grava usadas fueron áridos naturales, rodados y de naturaleza cuarcítica. La curva granulométrica resultante cumple con los requisitos de la norma TSI (15). El valor de absorción de la arena era de $1,5 \%$ y su densidad relativa (a superficie saturada seca, SSD) de 2,65.

El tamaño nominal máximo de la grava era de $16 \mathrm{~mm}$, con un valor de $0,99 \%$ de absorción y una densidad relativa (SSD) de 2,73. La curva granulométrica de los áridos se recoge en la Tabla 3. Se observa que la curva granulométrica de los áridos estaba situada entre los límites B y C excepto para el tamiz de $0,25 \mathrm{~mm}$.

\section{Superplastificante}

Se utilizó un superplastificante (SP) caboxílico comercial, reductor de agua, e idóneo para la elaboración de hormigones con ceniza volante. standard (<1.5\%). The content of $\mathrm{SiO}_{2}$ of fly ash $18.95 \%$ does not comply with ASTM (7) standard, because ASTM (7) requires it to be at least $40 \%$ for class $C$ fly ash. The total of $\mathrm{SiO}_{2}+\mathrm{Al}_{2} \mathrm{O}_{3}+\mathrm{Fe}_{2} \mathrm{O}_{3}$ of fly ash used is about $30 \%$, however, ASTM (7) standard restricts it to be at least $50 \%$. Although, fly ash used does not comply some of the requirements of standards, it complies some other requirements i.e. it complied with max fineness, because the remanining on $45 \mu$ mieve was $14 \%$ which was less than $40 \%$ of requirement of TSI (13) and EN (14), and less than $34 \%$ of ASTM (7), however, it did not comply with BSI (12) which requires it to be maximum $12.5 \%$. Loss on ignition value complied with all standards $(7,12,13,14)$. Pozzolanic activity index (PAI) of fly ash was found $84 \%$ and $92 \%$ at 28-days and 90-days respectively. PAI satisfied the TSI (13) and EN (14) criteria which are $75 \%$ and $85 \%$ at 28-days and 90-days respectively. Free lime contents of fly ash did not comply with TS (13) and EN (14) standards, because it is 3\%. Expansion test results also did not comply with TS (13) and EN (14) standards, because it was $41 \mathrm{~mm}$ which exceeds the minimum value specified by TS (13) and EN (14) standards (see Table 2). It did not comply with the requirements of BSI (12), and ASTM (7), TSI (13) and EN (14) due to its $\mathrm{SO}_{3}$ content. It did not comply with the limits of free lime content and expansion test. Therefore, it can be called as a non-standard ash.

\section{Aggregates}

The sand and aggregate used were uncrushed, quartzitic, natural aggregate. It was obtained from the natural deposit. The grading of mixed aggregate complied with the requirements of TSI (15). The absorption value of the sand used was $1.5 \%$ and its relative density at saturated surface dry (SSD) condition was 2.65 .

The gravel was $16 \mathrm{~mm}$ of maximum nominal size with a $0.99 \%$ absorption value and its relative density (SSD) was 2.73. Grading of the mixed aggregate was given in Table 3 with the relavant standard limits. It was seen from Table 3 that the grading of the aggregate was fallen into the limits between $B$ and $C$ which was considered to be usable zone.

\section{Superplasticizer}

The superplasticizer (SP) was a commercial carboxylic type high range water reducing agent suitable for fly ash blended concrete. 


\section{Composición del hormigón}

Para este trabajo, se prepararon tres hormigones con diferentes proporciones de cemento. Las proporciones cemento/ árido fueron de 1:10.5, 1:6.5, 1:4.5 en peso. Las cantidades aproximadas de cemento fueron de 200 , $300,400 \mathrm{~kg} / \mathrm{m}^{3}$, respectivamente. Para cada dosificación se emplearon dos relaciones a/c constantes de 0,5 y 0,8 y una relación óptima y la cantidad adecuada de superplastificante.

Con el propósito de evaluar la influencia de la ceniza en la resistencia a compresión, se elaboraron hormigones mixtos con un porcentaje de sustitución del $15 \%, 30 \%$, y $45 \%$ en peso de cemento. Las mezclas se elaboraron con y sin SP. La Tabla 4 presenta la composición de los hormigones producidos y ensayados.

\section{Concrete mixture composition}

In this laboratory work, three different concrete mixture proportions were prepared with three different quantity of cement for a unit volume of concrete. The mixture proportions were 1:10.5, 1:6.5, 1:4.5 cement and aggregate respectively. The given proportions for the cement and aggregate are in mass basis. The approximate quantity of cement used for the mixtures were $200,300,400 \mathrm{~kg} / \mathrm{m}^{3}$ respectively for each concrete mixture proportions. Two constant $w / c$ ratio 0.5 and 0.8 were chosen for each mixture proportions. Fresh concrete mixture were prepared with these constant $w / c$ ratio. Fresh concrete mixture were also prepared with the optimal w/c ratio as well as optimal w/c ratio plus $S P$.

For the purpose of evaluating the influence of the fly ash on compressive strength of concrete, fly ash (FA) concretes were produced using FA as cement replacement at the level of $15 \%, 30 \%$, and $45 \%$ by mass. The mixtures were made with and without a SP. Table 4 presents the composition of the concretes produced and tested.

\section{TABLA 3/TABLE 3}

Curva granulométrica de los áridos con Límite Normal (\%) que pasa) (Grading of mixed aggregate with Standard Limit (\% passed))

\begin{tabular}{|c|c|c|c|c|}
\hline $\begin{array}{c}\text { Abertura del } \\
\text { tamiz }(\mathrm{mm}) \\
\text { (Sieve size } \\
(\mathrm{mm})) \\
\end{array}$ & $\begin{array}{l}\text { Limite inferior de } \mathrm{TS}^{15} \\
\text { (A) } \\
\left.\text { (Lower limit of } T S^{15}(A)\right)\end{array}$ & \begin{tabular}{|c|}
$\begin{array}{c}\text { Límite medio de } \mathrm{TS}^{15} \\
(\mathrm{~B}) \\
\text { (Middle limit of } T S^{15} \\
(B))\end{array}$ \\
\end{tabular} & $\begin{array}{l}\text { Curva granulométrica } \\
\text { del árido usado } \\
\text { (Grading of the } \\
\text { aggregate used) } \\
\end{array}$ & $\begin{array}{c}\text { Limite superior de } \\
\operatorname{TS}^{15}(\mathrm{C}) \\
\text { (Upper limit of TS } 15 \\
(C))\end{array}$ \\
\hline 0.25 & 3 & 8 & 4.9 & 18 \\
\hline 1 & 12 & 32 & 41.4 & 49 \\
\hline 2 & 21 & 42 & 51.3 & 62 \\
\hline 4 & 36 & 56 & 62.9 & 74 \\
\hline 8 & 60 & 76 & 81.2 & 88 \\
\hline 16 & 100 & 100 & 100 & 100 \\
\hline
\end{tabular}

\section{TABLA 4/TABLE 4}

Proporciones de las mezclas de hormigón con a/c de $0.5,0.8$ y óptimo (Concrete mix proportions with w/c ratio of $0.5,0.8$ and optimum)

\begin{tabular}{|l|c|c|c|c|c|c|c|c|c|}
\hline $\begin{array}{c}\text { Designa } \\
\text { ción } \\
\text { (Name) }\end{array}$ & $\begin{array}{c}\text { Áridos } \\
(\mathrm{kg}) \\
\left(\begin{array}{c}\text { Mixed } \\
\text { aggregate) } \\
(\mathrm{kg}))\end{array}\right.\end{array}$ & $\begin{array}{c}\mathrm{C} \\
(\mathrm{kg})\end{array}$ & $\begin{array}{c}\mathrm{FA} \\
(\mathrm{kg})\end{array}$ & $\begin{array}{c}\mathrm{FA} \\
\mathrm{c}+\mathrm{FA} \\
\%\end{array}$ & $\begin{array}{c}\mathrm{w} \\
(\mathrm{Lt})\end{array}$ & $\begin{array}{c}\mathrm{a}(w) \\
\mathrm{c}+\mathrm{FA}\end{array}$ & $\begin{array}{c}\mathrm{SP} \\
(\mathrm{Lt})\end{array}$ & $\begin{array}{c}\mathrm{SP} \\
\mathrm{c}+\mathrm{FA} \\
\%\end{array}$ & $\begin{array}{c}\text { V-B Tiempo /(Time) } \\
\text { (sn) } \\
0.5 ; 0.8 ; \text { Opt; Opt+SP }\end{array}$ \\
\hline $\mathrm{K} 1$ & 2100 & 200 & 0 & 0 & $100(160) 164$ & $0.5(0.8) 0.82$ & 8.8 & 0.044 & $50(22) 17(10)$ \\
\hline $\mathrm{K} 2$ & 1950 & 300 & 0 & 0 & $150(240) 159$ & $0.5(0.8) 0.53$ & 9.0 & 0.030 & $35(7) 12(4)$ \\
\hline $\mathrm{K} 3$ & 1800 & 400 & 0 & 0 & $200(320) 160$ & $0.5(0.8) 0.40$ & 8.0 & 0.020 & $7(2) 14(3)$ \\
\hline $\mathrm{K} 1-15$ & 2100 & 170 & 30 & 15 & $100(160) 166$ & $0.5(0.8) 0.83$ & 8.8 & 0.044 & $50(18) 18(9)$ \\
\hline $\mathrm{K} 2-15$ & 1950 & 255 & 45 & 15 & $150(240) 162$ & $0.5(0.8) 0.54$ & 9.0 & 0.030 & $34(7) 11(4)$ \\
\hline $\mathrm{K} 3-15$ & 1800 & 340 & 60 & 15 & $200(320) 164$ & $0.5(0.8) 0.41$ & 8.0 & 0.020 & $8(2) 8(4)$ \\
\hline $\mathrm{K} 1-30$ & 2100 & 140 & 60 & 30 & $100(160) 168$ & $0.5(0.8) 0.84$ & 8.8 & 0.044 & $55(15) 12(8)$ \\
\hline $\mathrm{K} 2-30$ & 1950 & 210 & 90 & 30 & $150(240) 165$ & $0.5(0.8) 0.55$ & 9.0 & 0.030 & $30(7) 10(4)$ \\
\hline $\mathrm{K} 3-30$ & 1800 & 280 & 120 & 30 & $200(320) 168$ & $0.5(0.8) 0.42$ & 8.0 & 0.020 & $7(2) 15(5)$ \\
\hline $\mathrm{K} 1-45$ & 2100 & 110 & 90 & 45 & $100(160) 170$ & $0.5(0.8) 0.85$ & 8.8 & 0.044 & $60(20) 14(6)$ \\
\hline $\mathrm{K} 2-45$ & 1950 & 165 & 135 & 45 & $150(240) 168$ & $0.5(0.8) 0.56$ & 9.0 & 0.030 & $35(6) 9(6)$ \\
\hline $\mathrm{K} 3-45$ & 1800 & 220 & 180 & 45 & $200(320) 176$ & $0.5(0.8) 0.44$ & 8.0 & 0.020 & $6(2) 14(6)$ \\
\hline
\end{tabular}


La proporción óptima de agua/cemento fue determinada mediante el método"Weber", descrito en referencia (16). El cual determina la relación óptima a/c que correspondería a la máxima compacidad del hormigón. En la Tabla 4, columna a/(c+FA) bajo O, se recoge las proporciones óptimas encontradas para los hormigones elaborados.

Los hormigones sin ceniza volante se designan como $\mathrm{K} 1, \mathrm{~K} 2$, y K3, los cuales se toman como referencia. Los hormigones designados como K1-15, K2-15, K3-15; $\mathrm{K} 1-30, \mathrm{~K} 2-30$, K3-30 y K1-45, K2-45, K3-45 corresponden a los hormigones mixtos con porcentaje de ceniza volante del $15 \%, 30 \%$ y $45 \%$, respectivamente.

Las mezclas de hormigón elaboradas con la relación a/c óptima mostraban valores cero de asentamiento, lo que indica hormigones de consistencia seca no trabajables. Los hormigones fabricados con una relación a/c de 0,5 , también eran mezclas no trabajables, excepto para la mezcla $\mathrm{K} 3$ con ceniza volante. Con las mezclas de hormigón elaboradas con la proporción óptima y superplastificante se obtuvieron hormigones fluidos y trabajables. El uso de SP fue muy eficaz, para todas las mezclas de hormigón, excepto para el caso del hormigón $\mathrm{K} 1$ con y sin cv ya que porque la cantidad de cemento usada fue realmente menor por metro cúbico. Los valores de asentamiento para las mezclas de hormigones superplastificadas $\mathrm{K} 2$ y $\mathrm{K} 3$ estaban comprendidas entre 500 y $600 \mathrm{~mm}$.

En la Tabla 4 puede verse cómo aumentando la proporción de $\mathrm{cv}$, aumenta la relación a/c óptima para un hormigón conteniendo la misma cantidad de masa cementante $\left(200,3000400 \mathrm{~kg} / \mathrm{m}^{3}\right)$. Esto muestra que la ceniza de "Afsin-Elbistan" tiende a aumentar la cantidad de agua necesaria para la mezcla. Este hecho puede ser debido tanto a la pérdida por calcinación como al porcentaje retenido de las partículas gruesas en el tamiz de $45 \mu \mathrm{m}$.

\section{Procedimiento de ensayo, preparación de probetas cúbicas y curado}

En el laboratorio se determinaron las resistencias a compresión de los hormigones curados en una cámara húmeda a $20^{\circ} \mathrm{C}$ de temperatura $\mathrm{y}$, las resistencias a compresión de los hormigones curados con métodos acelerados, usando el método de agua caliente (MAC) y el método de agua hirviendo (MAH).

Para cada hormigón se prepararon 12 probetas cúbicas de $150 \mathrm{~mm}$. Tres probetas cúbicas por cada resistencia a determinar (28 días y 3 meses), tres más para el curado
Optimal w/c ratio was determined by vibrating slump test using the soil phylosphy. Vibrating slump test is described elsewhere (16). It determines the optimal $w / c$ ratio according to the fact that optimum $w / c$ ratio corresponds to the maximum compactability, thus, the density. Although the details are not given, the optimal $w / c$ ratios found for each concrete composition were given in Table 4 at the column of $w /(c+F A)$ under $O$.

$K 1, K 2, K 3$ are the concretes made with Portland cement only and considered as the control concrete. The group of K1-15,K2-15,K3-15 and the group of $K 1-30, K 2-30, K 3-30$ and the group of K1-45, K2-45, $K 3-45$ concretes were made with $F A$ replacing the cement at a replacement ratio $15 \%, 30 \%, 45 \%$ by modification of K1,K2, K3 Portland cement concrete mixtures.

The concrete mixtures made with optimum water cement ratio were non-workable zero-slump concrete. The concretes made with $0.5 \mathrm{w} / \mathrm{c}$ ratio were also nonworkable except the concrete $K 3$ and its modification with $F A$. The concrete mixtures made with optimum $w / c$ ratio and SP were high workable flowing concrete. The use of SP was very effective. The mixtures containing it were practically flowable except the concrete $K 1$ and its modification with FA. The SP did not work with $K 1$ and its modifications with FA because the amount of cement used was quite less for a unit volume. The values from the flow table were within 500-600 mm for suprplasticised K2, K3 mixes and their modification with $F A$.

It can be seen from Table 4 that, increasing the replacement ratio of FA increases the optimum waterbinder ratio for a concrete containing specific amount of binder such as 200, 300 or $400 \mathrm{~kg} / \mathrm{m}^{3}$ binder. This shows that the ash of Afsin-Elbistan tends to increase the amount of water needed for fresh mixture. This is possible due to the loss on ignition of FA as well as its coarser particles remaining on $45 \mu \mathrm{m}$ sieve.

\section{Testing procedure and preparation of sample and curing}

In the laboratory, the compressive strength of concrete cured in moist room at $20^{\circ} \mathrm{C}$ temperature, and the compressive strength of concrete cured with accelerated curing using warm-water method (WWM) and boiling-water method ( $B W M)$ were measured. The strength measurements were carried out on all the mixtures produced.

Three cubes were used for each strength measurement. For each concrete, 12 cube specimens with $150 \mathrm{~mm}$ side were prepared. Three of the cubes were used for 28 
acelerado con el método de agua caliente y las otras tres para el curado acelerado con método de agua hirviendo. Un total de 576 probetas cúbicas se elaboraron para las 48 mezclas de hormigón elaboradas. Los procedimientos de ensayo para los ensayos acelerados MAC y MAH se llevó a cabo de acuerdo con las normas ASTM (17) y TSI (18).

\section{RESULTADOS Y DISCUSIÓN}

\section{Resistencia a compresión a 28 días y 3 meses de curado}

Los resultados de resistencia a compresión con el curado normal en una cámara húmeda y a una temperatura de $20^{\circ} \mathrm{C}$ se presentan en las Tablas 5-8. La Tabla 5 muestra la resistencia a compresión del hormigón con una relación a/c de 0,5 . Se observa que con una relación $\mathrm{a} / \mathrm{c}$ de 0,5 y entre 300 y $400 \mathrm{~kg} / \mathrm{m}^{3}$ de masa cementante, con un a $15 \%$ de cv, se puede obtener resistencias a compresión entre 45-50 MPa. Es decir, que el hormigón elaborado con un $15 \%$ de $\mathrm{cv}$ se puede obtener

\section{TABLA 5/TABLE 5}

Resistencia a compresión de hormigón (MPa) hecho con a/c de 0.5 a 28 días y 3 meses (Compressive strength of concrete (MPa) made with $0.5 \mathrm{w} / \mathrm{c}$ ratio at 28 days and 3 montths)

\begin{tabular}{|c|c|c|c|c|}
\hline $\begin{array}{c}\text { Mezcla y proporción de sustitución } \\
\text { (Mix and rep.ratio) }\end{array}$ & $0 \%$ & $15 \%$ & $30 \%$ \\
\hline K 1 & $5.72(4.80)$ & $4.92(5.77)$ & $4.97(3.71)$ & $3.27(4.80)$ \\
\hline K 2 & $43.05(53.16)$ & $42.32(49.31)$ & $31.06(33.76)$ & $18.26(22.65)$ \\
\hline K 3 & $47.13(56.62)$ & $48.73(51.62)$ & $46.89(54.98)$ & $39.22(46.89)$ \\
\hline
\end{tabular}

TABLA $6 / T A B L E 6$

Resistencia a compresión de hormigón (MPa) hecho con a/c de 0.8 a 28 días y 3 meses (Compressive strength of concrete (MPa) made with $0.8 \mathrm{w} / \mathrm{c}$ ratio at 28 days and 3 months)

\begin{tabular}{|c|c|c|c|c|}
\hline $\begin{array}{c}\text { Mezcla y proporción de sustitución } \\
\text { (Mix and rep.ratio) }\end{array}$ & $0 \%$ & $15 \%$ & $30 \%$ \\
\hline K 1 & $17.34(18.43)$ & $8.79(9.55)$ & $7.74(8.44)$ & $4.83(7.76)$ \\
\hline K 2 & $20.66(27.06)$ & $18.17(24.56)$ & $11.05(20.90)$ & $5.74(14.23)$ \\
\hline K 3 & $24.41(29.37)$ & $20.56(25.54)$ & $14.83(22.06)$ & $6.13(12.56)$ \\
\hline
\end{tabular}

TABLA 7/TABLE 7

Resistencia a compresión de hormigón (MPa) hecho con la proporción de a/c óptima a 28 días y 3 meses (Compressive strength of concrete (MPa) made with optimal w/a ratio at 28 days and 3 months)

\begin{tabular}{|c|c|c|c|c|}
\hline $\begin{array}{c}\text { Mezcla y proporción de sustitución } \\
(M i x \text { and rep.ratio) }\end{array}$ & $0 \%$ & $15 \%$ & $30 \%$ & $45 \%$ \\
\hline $\mathrm{K} 1$ & $22.57(23.64)$ & $25.89(28.91)$ & $18.20(23.28)$ & $11.88(19.58)$ \\
\hline $\mathrm{K} 2$ & $46.93(53.49)$ & $49.18(54.34)$ & $39.83(42.35)$ & $18.48(34.58)$ \\
\hline K 3 & $60.84(64.33)$ & $62.96(70.81)$ & $44.80(60.83)$ & $27.00(30.10)$ \\
\hline
\end{tabular}

TABLA $8 / T A B L E 8$

Resistencia a compresión de hormigón (MPa) hecho con la proporción óptima de a/c y usando SP a 28 días y 3 meses (Compressive strength of concrete (MPa) made with optimal w/a ratio and using SP at 28 days and 3 months)

\begin{tabular}{|c|c|c|c|c|}
\hline $\begin{array}{c}\text { Mezcla y proporción de sustitución } \\
\text { (Mix and rep.ratio) }\end{array}$ & $0 \%$ & $15 \%$ & $30 \%$ \\
\hline K 1 & $18.65(21.65)$ & $18.61(22.41)$ & $17.11(19.05)$ & $16.13(17.28)$ \\
\hline K 2 & $45.66(51.29)$ & $44.58(53.49)$ & $35.21(43.84)$ & $28.84(36.41)$ \\
\hline K 3 & $59.64(71.49)$ & $61.33(75.56)$ & $56.02(63.49)$ & $31.12(49.29)$ \\
\hline
\end{tabular}


resistencias comparables al hormigón de referencia (ver Tabla 5, filas K1, K2, K3). K1 no desarrolló resistencias considerables por el nivel de cv sustituida.

La Tabla 6 presenta las resistencias a compresión de los hormigones elaborados con una relación $\mathrm{a} / \mathrm{c} \mathrm{de}$ 0,8. Los hormigones $\mathrm{K} 2$ y K3 desarrollaron resistencias más bajas que los hormigones correspondientes a 0,5 . verificando que una relación $\mathrm{a} / \mathrm{c}$ creciente, disminuye la resistencia a compresión. Por el contrario, el hormigón $\mathrm{K} 1(\mathrm{a} / \mathrm{c}$ de 0,8$)$ desarrollaba resistencias más altas que el hormigón $\mathrm{K} 1$ elaborado con relación de 0,5 . Esto se debe al hecho de que la cantidad de agua para la relación de 0,5 no era suficiente para mezclar el hormigón K1 con 200 $\mathrm{kg} / \mathrm{m}^{3}$ de cemento $+\mathrm{cv}$. Tabla 6 también muestra que no hay ninguna posibilidad de usar una alta cantidad de material cementante, cuando la relación a/c sea tan alta como 0,8 .

En la Tabla 7 se presentan las resistencias a compresión de los hormigones a 28 días y 3 meses de curado, producidos con la relación a/c óptima. En ella, se muestra que el hormigón claborado con la proporción óptima de $\mathrm{a} / \mathrm{c}$ desarrolló las resistencias más alta que el hormigón elaborado con las relaciones de 0,5 y 0,8 . Para los hormigones K2 y K3 puede explicarse con la regla de la relación a/c de Duff Abraham (19), la cual establece que para relaciones a/c decrecientes, las resistencias aumentan. Sin embargo, esta regla no puede explicar lo que sucedió para el caso de $\mathrm{K} 1$, donde la relación óptima de a/c era más alta que para los mismos hormigones elaborados con 0,5 y 0,8 . Para $\mathrm{K} 1$ se puede explicar atendiendo a la trabajabilidad y compacidad de las mezclas de hormigón. El hormigón fabricado con una relación a/c de 0,5 era un hormigón muy seco. El descenso de las resistencias a compresión para los hormigones $\mathrm{K} 1$ se atribuyó a su baja relación a/c, la cual produjo hormigones muy secos y difíciles de compactar.

La Tabla 7 también muestra que a 28 días y 3 meses de curado, los hormigones conteniendo un $15 \%$ de cv desarrollaron resistencias a compresión más altas que los hormigones de referencia. Los hormigones que contienen $30 \%$ de $\mathrm{cv}$ no desarrollaron resistencias altas a 28 días, pero sí a los 3 meses de curado.

Las resistencias de los hormigones con relación óptima y aditivados se presentan en Tabla 8. Los resultados encontrados muestran que no hay mucha diferencia entre el uso o no de SP en cuanto a resistencias se refiere; excepto para $\mathrm{K} 1$. El empleo de superplastificante en este tipo de hormigones resultó negativo. Esto se atribuye al contenido muy alto de aditivo utilizado, aunque los hormigones mostraban una mayor trabajabilidad. containing cement only (see Table 5, rows of $K 1, K 2$, $K 3) . K 1$ did not develop considerable strength for all level of FA replacement.

Table 6 shows the strength of concrete made with 0.8 $w / c$ ratio. It shows that $K 2$ and $K 3$ concrete developed lower strength than those corresponding to concretes made with $0.5 \mathrm{w} / \mathrm{c}$ ratio showing that increasing $w / c$ decreased the compressive strength. On contrary, Kl concrete made with $0.8 \mathrm{w} / \mathrm{c}$ developed higher strength than that of counterpart K1 concrete made with $0.5 \mathrm{w} / \mathrm{c}$. This is happened due to the fact that the amount of water for $0.5 \mathrm{w} / \mathrm{c}$ ratio was not good enough to mix the KI concrete with $200 \mathrm{~kg} / \mathrm{m}^{3}$ binder. Table 6 also shows that there is no possibility of using high amount of binder when the w/c ratio is so high as 0.8 .

The 28-days and 3-months compressive strengths of the concrete produced with optimal $w / c$ ratio are presented in Table 7. It shows that the concrete produced with the optimal $w / c$ ratio developed higher strength than the concrete produced with 0.5 and $0.8 \mathrm{w} / \mathrm{c}$ ratio. This can be explained for $K 2$ and $K 3$ using the Duff Abraham's wic cratio (19) rule that decreasing $W / C$ increases the strength. However, Abraham's rule cannot explain the situation happened for KI because optimal w/c for $K 1$ group is higher than 0.5 and $0.8 \mathrm{w} / \mathrm{c}$ ratio. The situation of $K 1$ is explained using workability and compaction of concrete mixture. The concrete made with $0.5 \mathrm{w} / \mathrm{c}$ was a very dry concrete. Very low compresive strength of $K 1$ group of concrete with $0.5 \mathrm{w} / \mathrm{c}$ ratio was attributed to the low $w / c$ ratio of 0.5 that produced very dry concrete which cannot be compacted properly.

Table 7 also shows that the concrete containing 15\% of FA developed higher 28 days and 3 months compressive strength than that of counterpart Portland cement concrete. The concretes containing 30\% FA did not developed higher strength at 28 days, however, they developed comparable strength at 3 months of age.

The strengths of concretes made with optimal w/c and with the use of SP are given in Table 8. The results obtained show that there is not much difference between the use and no use of SP in terms of strength, except for $K 1$ concrete. The use of SP resulted lower strength for $K 1$ group of concrete. This is attributed to the use of very high dossage of SP with Kl concretes regardless of it contained FA. However, the use of SP resulted higher workability. 
Se llevo a cabo ún análisis estadístico para relacionar la resistencia a compresión del hormigón a 28 días y de los 3 meses sin tener en cuenta el material cementante, cv, aditivo y contenido de agua. La relación y el factor de correlación se presentan en la Figura 1. Los resultados muestran una buena relación entre la resistencia obtenida a 28 días y los 3 meses de curado, como también la existente para el hormigón de cemento Portland convencional (19-22). Las líneas superiores y inferiores corresponden al $90 \%$ de nivel de confianza.

De los datos de resistencia a compresión obtenidos, podría obtenerse que la ceniza de "Afsin-Elbistan" podría usarse en el hormigón entre 15 y $30 \%$ como sustitución de cemento. Sin embargo, antes de hacer esta recomendación sería necesario llevar a cabo una investigación más extensa con el objeto de determinar otras propiedades del hormigón, tales como: resistencia a flexotracción, abrasión, porosidad, permeabilidad y durabilidad.

\section{Resistencia a compresión de los hormigones curados por el Método de Agua Caliente y Agua Hirviendo}

Los resultados de resistencia obtenidos, aplicando los métodos acelerados MAC y MAH están en las Tablas 9-12. Los resultados correspondientes al MAH se recogen entre paréntesis. La relación entre la resistencia a 28 días y la resistencia a curado acelerado se discute en la próxima sección.

\section{Relación entre la resistencia a compresión del hormigón obtenido por curado normal y acelerado}

Usando los datos presentados en las Tablas 5-12, se realizó una tentativa para establecer una relación entre la resistencia normal y la resistencia de curado acelerado a los 28 días de curado. La relación se
A statistical analysis was made to relate 28-days strength and 3-months strength of the concrete produced regardless of its binder, FA, SP and water content. The relation was given in Figure 1 with the equation developed with 0.96 of $r^{2}$. The results show that a good relation exist between 28-days and 3months strength as existed for conventional Portland cement concrete (19-22). The upper and lower bands in Figure 1 are 90\% confidence level of the relationship established.

From the compressive strength data obtained, it could be concluded that Afsin-Elbistan ash might be used in concrete between 15 and $30 \%$ as cement replacement. However, before making sound conclusion, further research is needed regarding other properties of the concrete produced including flexural and cylinder splitting tensile strength, abrasion resistance shrinkage, porosity, permeability and durability.

\section{Compressive strength of Concrete Accelerated by Warm-Water and Boiling-Water Curing Method}

The results of the accelerated strength measurement with $W W M$ and BWM are given in Table 9-12. BWM results are given in paranthesis. The relation between 28-days strength and the accelerated strength of concrete was discussed in the next section.

\section{Relation between compressive strength of concrete obtained by normal curing and accelerated curing}

Using the data given in Table 5-12, an attempt was made to establish a relationship between 28 days strength and the accelerated strength of the concretes produced. The relationship was established between 28 days strength

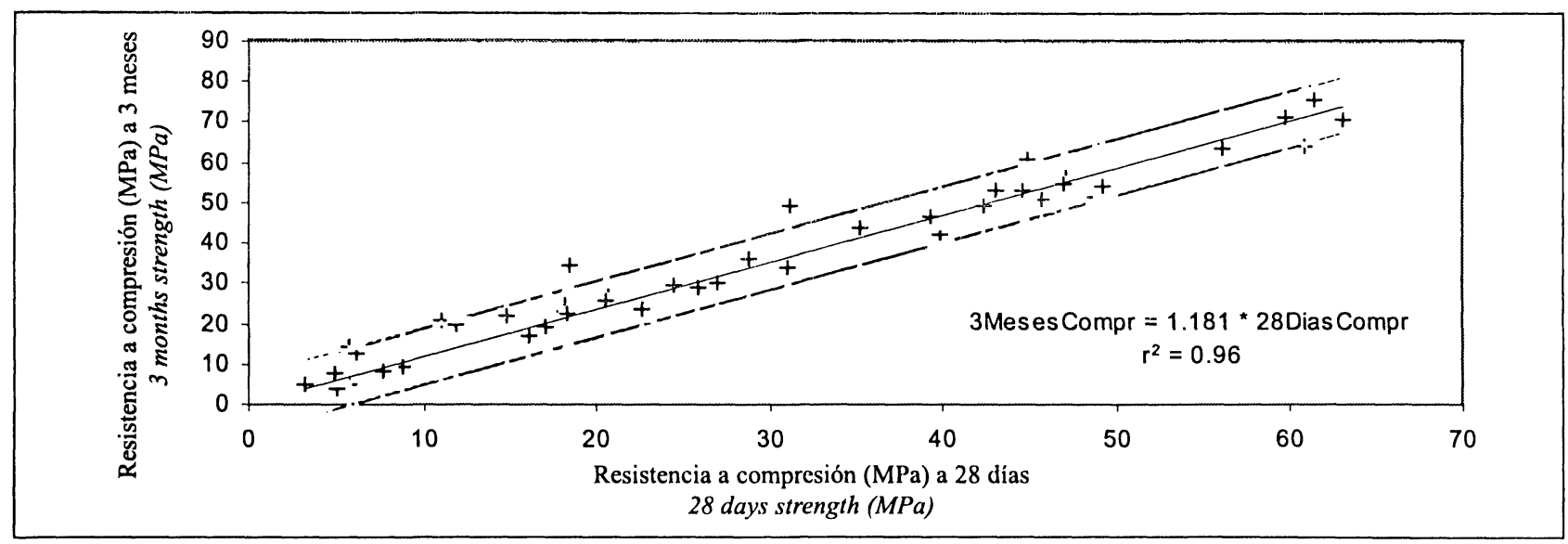

Figura 1.- Relación entre la resistencia a 28 días y 3 meses.

Figure 1.- Relation between 28 days strength and 3 months strength. 
estableció entre la resistencia normal a los 28 días y la resistencia con curado de agua caliente $y$, entre la resistencia normal a los 28 días y la resistencia con curado a agua hirviendo. En las Figuras 2 y 3 se presentan las relaciones encontradas respectivamente. Las líneas superiores e inferiores limitan el $90 \%$ de nivel de confianza. En ellas se muestra que una relación buena existe entre los resultados de resistencia con curado normal y acelerado. El análisis de resultados de ensayo and warm-water accelerated strength, it was also established between 28-days strength and boilingwater accelerated strength. The relationships found were presented in Figure 2 and 3 respectively. The upper and lower band lines show $90 \%$ confidence level of the relationship in both figures. Figure 2 and 3 shows that a good relationship exists between both accelerated and normal strength testing. The analysis of laboratory test results also indicated that 28 days

TABLA 9/TABLE 9

Resistencia a compresión acelerada (MPa) del hormigón hecho con a/c de 0.5 (MAC (MAH))

(Accelerated compressive strength (MPa) of concrete made with $0.5 \mathrm{w} / \mathrm{c}$ ratio (WWM (BWM))

\begin{tabular}{|c|c|c|c|c|}
\hline $\begin{array}{c}\text { Mezcla y proporción de sustitución } \\
\text { (Mix and rep.ratio) }\end{array}$ & $0 \%$ & $15 \%$ & $30 \%$ & $45 \%$ \\
\hline $\mathrm{K} 1$ & $2.54(2.77)$ & $2.57(2.26)$ & $2.18(1.74)$ & $1.84(1.82)$ \\
\hline $\mathrm{K} 2$ & $19.84(21.77)$ & $31.14(22.22)$ & $18.89(15.98)$ & $10.50(11.17)$ \\
\hline $\mathrm{K} 3$ & $29.68(23.93)$ & $28.14(32.24)$ & $23.06(16.74)$ & $15.28(15.25)$ \\
\hline
\end{tabular}

TABLA $10 / T A B L E 10$

Resistencia a compresión acelerada (MPa) de hormigón hecho con a/c de 0.8 (MAC (MAH)) (Accelerated compressive strength (MPa) of concrete made with $0.5 \mathrm{w} / \mathrm{c}$ ratio (WWM (BWM))

\begin{tabular}{|c|c|c|c|c|}
\hline $\begin{array}{c}\text { Mezcla y proporción de sustitución } \\
\text { (Mix and rep.ratio) }\end{array}$ & $0 \%$ & $15 \%$ & $30 \%$ & $45 \%$ \\
\hline $\mathrm{K} 1$ & $7.01(6.38)$ & $8.22(7.82)$ & $4.27(7.57)$ & $5.99(4.70)$ \\
\hline $\mathrm{K} 2$ & $8.97(5.61)$ & $10.75(5.56)$ & $5.97(3.23)$ & $4.19(2.09)$ \\
\hline $\mathrm{K} 3$ & $8.61(6.94)$ & $6.78(4.69)$ & $8.10(2.67)$ & $3.48(1.89)$ \\
\hline
\end{tabular}

\section{TABLA 11/TABLE 11}

Resistencia a compresión acelerada (MPa) de hormigón hecho con la proporción óptima de a/c (MAC (MAH)) (Accelerated compressive strength (MPa) of concrete made with optimal w/c ratio WWM (BWM))

\begin{tabular}{|c|c|c|c|c|}
\hline $\begin{array}{c}\text { Mezcla y proporción de sustitución } \\
\text { (Mix and rep.ratio) }\end{array}$ & $0 \%$ & $15 \%$ & $30 \%$ & $45 \%$ \\
\hline $\mathrm{K} 1$ & $10.25(9.36)$ & $12.04(9.62)$ & $10.38(7.47)$ & $6.31(5.15)$ \\
\hline $\mathrm{K} 2$ & $18.42(17.02)$ & $21.75(20.02)$ & $15.43(11.83)$ & $8.01(6.26)$ \\
\hline $\mathrm{K} 3$ & $38.81(33.21)$ & $32.98(32.14)$ & $22.38(20.44)$ & $13.35(11.66)$ \\
\hline
\end{tabular}
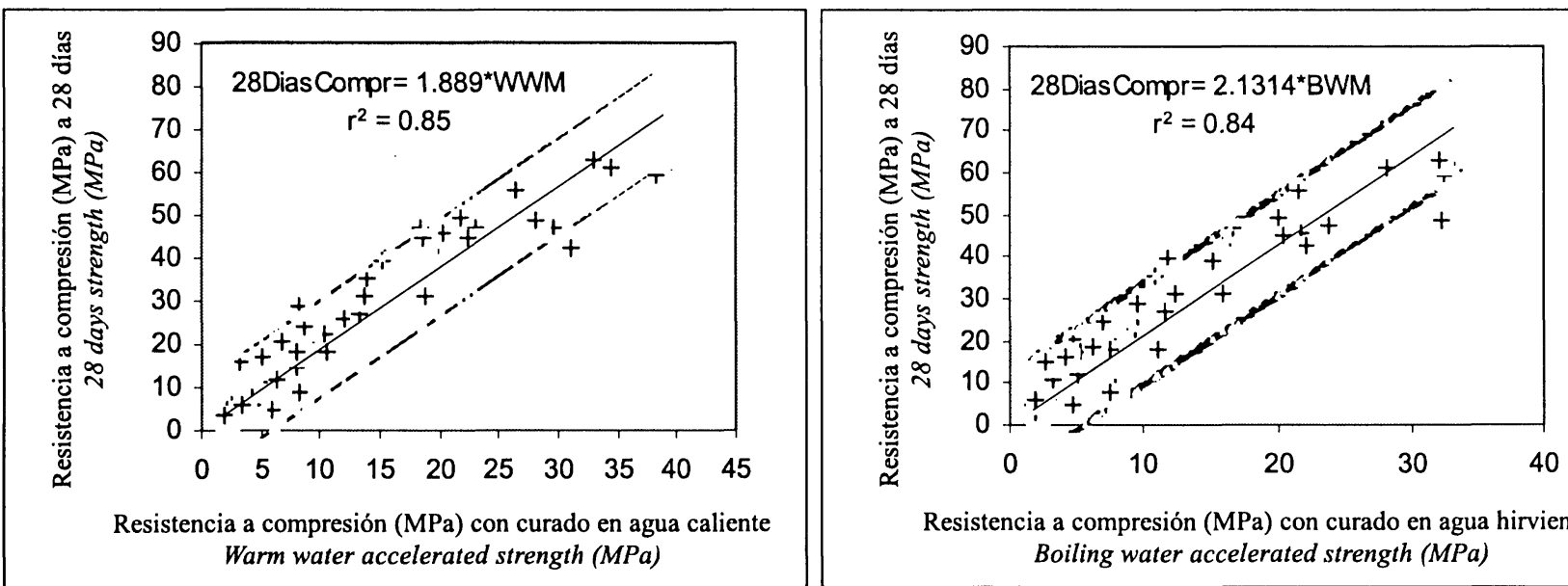

Resistencia a compresión (MPa) con curado en agua hirviendo Boiling water accelerated strength (MPa)

Figuras 2 y 3.- Relación entre la resistencia de los 28 días y la resistencia acelerada.

Figures 2 and 3.- Relation between 28 days strength and accelerated strength. 
TABLA 12/TABLE 12

Resistencia de compresión acelerada (MPa) de hormigón hecho con la proporción óptima de a/c y usando SP (MAC (MAH)) (Accelerated compressive strength (MPa) of concrete made with optimal w/c ratio and using SP (WWM (BWM))

\begin{tabular}{|c|c|c|c|c|}
\hline $\begin{array}{c}\text { Mezcla y proporción de sustitución } \\
\text { (Mix and rep. ratio) }\end{array}$ & $0 \%$ & $15 \%$ & $30 \%$ & $45 \%$ \\
\hline K1 & $6.93(7.83)$ & $6.74(6.56)$ & $4.97(5.19)$ & $3.27(4.09)$ \\
\hline K2 & $20.19(21.72)$ & $18.50(16.44)$ & $14.04(10.93)$ & $8.15(9.49)$ \\
\hline K3 & $38.15(32.48)$ & $34.36(28.12)$ & $26.50(21.53)$ & $13.80(12.45)$ \\
\hline
\end{tabular}

en el laboratorio también indicó que las resistencias a los 28 días de curado se pueden predecir con un coeficiente de correlación del $85 \%$.

Un análisis estadístico se llevó a cabo para estableccr una relación entre la resistencia obtenida con curado de agua caliente y la resistencia con agua hirviendo. El análisis de los resultados se recogen en la Figura 4. En ella se muestra la existencia de una buena relación entre las dos resistencias obtenidas con curado acelerado, con un $\mathrm{r}^{2}$ de 0,93. Las líncas superiores e inferiores, en la Figura 4, limitan el $90 \%$ de nivel de confianza. El uso del método MAC se recomienda aquí porque es más fácil y más corto que el método MAH.

Otro análisis estadístico se llevó a cabo para encontrar si el uso de cv influye en la resistencia de curado acelerado del hormigón estudiado. Para lograr ese propósito, la proporción de sustitución de cv se consideró como un parámetro, así se estableció la relación entre la resistencia a curado normal a los 28 días y la resistencia de curado acelerado para cada nivel de sustitución. Como resultado de los análisis, los valores de $\mathrm{r}^{2} \mathrm{y}$ de la pendiente encontrados se recogen en la Tabla 13. Dicha Tabla refleja que no hay una relación clara entre las proporciones de sustitución y los valores de $\mathrm{r}^{2}$. Se concluyó que la cantidad de cv no afectaba a la predicción de resistencia. Estos resultados están totalmente de acuerdo con los datos publicados por Tokyay (23). strength of concrete could be predicted with $85 \%$ correlation coefficient using the relationship found.

A statistical analysis was carried out to establish a relationship between warm-water accelerated strength and boiling-water accelerated strength. Analysis results given in Figure 4 showed that there is a good relation between both accelerated strengths with $r^{2}$ of 0.93. The upper and lower band lines in Figure 4 show 90\% confidence level of the relationship existed. The use of WWM is recommended here because it is easier to perform when compared to $B W M$, also it takes 3.5 hours shorter than that of $B W M$.

Another statistical analysis was carried out to find if the use of FA influences on accelerated strength of the concrete studied. To achieve that purpose, FA replacement ratio was considered a parameter, then the relation between 28-days strength and the accelerated strength of the concrete containing FA was established seperately for each replacement level. The relation considered was a ratio model. As a result of analysis $r^{2}$ and the slope value of each relation were found and given in Table 13 which shows that there is no clear relation between the changes in replacement ratio and slope value and $r^{2}$. From this, it was concluded that the amount of FA was immaterial in the strength prediction. These findings are totally in agreement with the data reported by Tokyay (23).

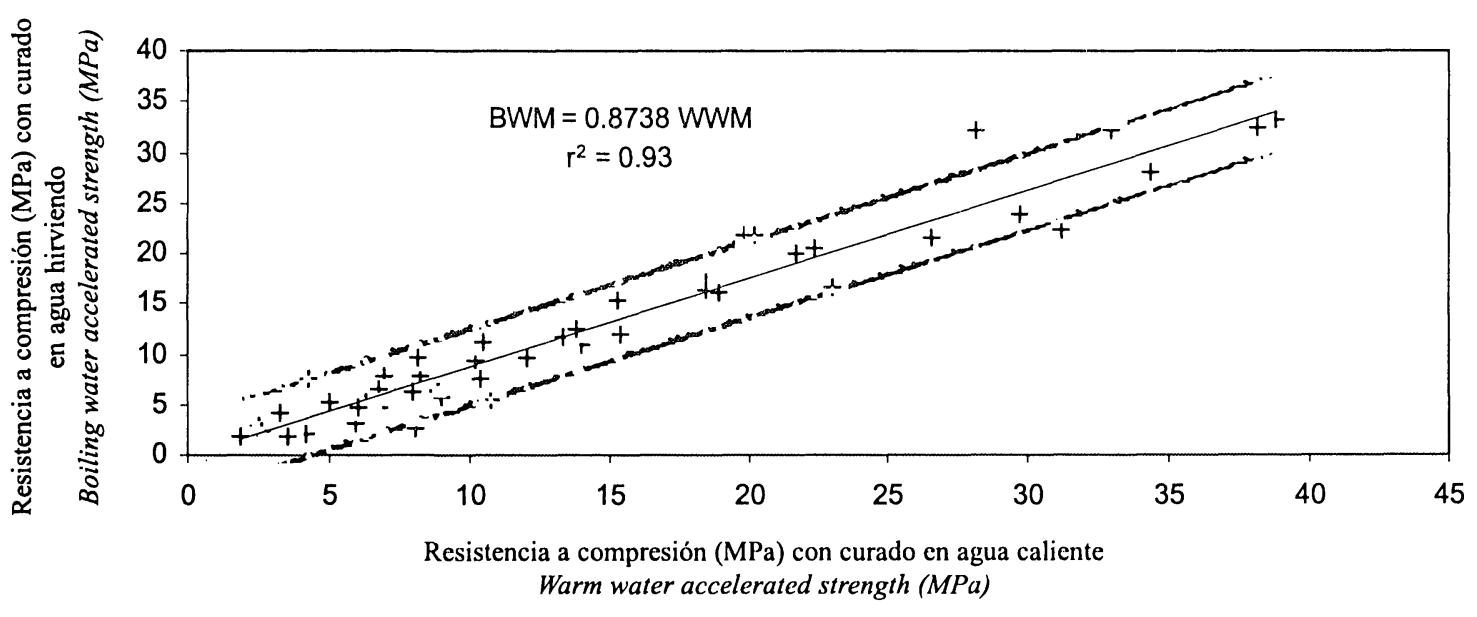

Figura 4.- Relación entre la resistencia acelerada de los métodos de curado de agua caliente y agua hirviendo. Figure 4.- Relation between warm-water and boiling-water accelered strength. 
TABLA 13/TABLE 13

$\mathrm{r}^{2}$ y los valores de declive (a) de la relación entre la resistencia acelerada y resistencia de los 28 días

$\left(r^{2}\right.$ and the slope (a) values of the relation between the accelerated strength and 28 days strength)

\begin{tabular}{|c|c|c|c|c|}
\hline & $0 \%$ & $15 \%$ & $30 \%$ & $45 \%$ \\
\hline WWM a, $\mathrm{r}^{2}$ & $1.79(0.80)$ & $1.82(0.86)$ & $2.07(0.93)$ & $2.25(0.77)$ \\
\hline BWM a, $\mathrm{r}^{2}$ & $1.92(0.86)$ & $2.01(0.82)$ & $2.52(0.84)$ & $2.42(0.90)$ \\
\hline
\end{tabular}

\section{CONCLUSIONES}

De los resultados del laboratorio pueden obtenerse las siguientes conclusiones:

1- La cv “Afsin-Elbistan” podría ser utilizarse hasta un $30 \%$ de sustitución en la producción de hormigones.

2- La resistencia de los hormigones con cv a 28 días de curado se podrá predecir usando la resistencia obtenida con el método de curado acelerado MAC o MAH, con un $85 \%$ de $\mathrm{r}^{2}$.

3- Existe un buena relación entre ambos métodos acelerados (con un $\mathrm{r}^{2}$ del 93\%).

4- Se recomienda el método MAC, por su facilidad de uso y menor tiempo de ensayo.

5- La cantidad de ceniza utilizada no influye a la hora de predecir la resistencia a compresión.

\section{AGRADECIMENTOS}

Los autores agradecen al Fondo de apoyo financiero de la Universidad de Çukurova, Turquia por su financiación a este trabajo de Investigación (Número de Proyecto MMF.2000.21 y MMF.2001.20).

\section{CONCLUSIONS}

From the results of laboratory study the following conclusion can be made;

1-Afsin-Elbistan fly ash could be used up to $30 \%$ in concrete production provided that trials carried out.

2-The 28 days strength of fly ash concrete could be predicted using WWM or BWM accelerated strength with $85 \%$ of $r^{2}$.

3-There is a good relationship between both accelerated curing methods, with 93\% of $r^{2}$.

4-The WWM is recommended, due to its ease of use and saving time.

5-In the strength prediction, the amount of fly ash was found to be immaterial.

\section{ACKNOWLEGEMENTS}

Authors thank to Cukurova University Research Fund for financial support to this work (Project Number MMF.2000.21 and MMF:2001.20).

\section{BIBLIOGRAFÍA}

(1) E. E. Berry, V. M. Malhotra. Fly Ash in Concrete. p.178, CANMET Pubs. (1986).

(2) V. M. Malhotra: Fly ash, silica fume and rice-husk ash in concrete: A review. Concrete International, Vol.15, No.4 (1993), pp.23-28.

(3) P. K. Mehta: Pozzolanic and cementitious by-products as mineral admixtures for concrete - A critical review.. Proceedings of $1^{\text {st }}$ International Conference on the use of Fly Ash, Silica Fume, Slag and Other Mineral By-Products in Concrete, ACI SP-79, Detroit,(1983), pp. 1-48.

(4) F. Massazza: Evolution of Cements and Cementitious Systems: History and Prospects. Proceedings of $2^{\text {nd }}$ Int. Symposium on Cement and Concrete Technology in the $2000 \mathrm{~s}$, Istanbul, Turkey (2000), pp.3-28.

(5) J. G. Cabrera, C. J. Hopkins, G. R. Woolley, R. E. Lee, J. Shaw, C. Plowman, and H. Fox: Evaluation of the properties of British pulverized fuel ashes and their influence on the strength of concrete. Proceedings of $2^{\text {nd }}$ International Conference on the use of Fly Ash, Silica Fume, Slag and Natural Pozzolans in Concrete, ACI SP-91, Madrid, Spain (1986), pp. 115-144.

(6) T. Y. Erdoðan. Admixtures for Concrete. p. 188, The Middle East Technical University Press (1997).

(7) ASTM. C-618-Standard Specification for Fly Ash and Raw Calcined Natural Pozzolan for Use as a Mineral Admixture in Portland Cement Concrete. Annual Book of ASTM Standard. (1991).

(8) C. D. Atis. Design and Properties of HVFA Concrete for Pavements. PhD Thesis, Leeds University, UK (1997). 
(9) Y. Zhang, W. Sun, and L. Shang: Mechanical properties of high performance concrete made with high calcium high sulfate fly ash. Cement and Concrete Research, Vol.27, No.27 (1997), pp.1093-1098.

(10) M. Tokyay and K. Erdoðdu. Characterization of fly ash obtained from Turkish thermal power plant, TÇMB/ARGE/Y98.3, Ankara (1998) (in Turkish).

(11) TSI. TS 19-Portland Cements. Ankara (1992) (in Turkish).

(12) BSI. BS 3892- Specification for Pulverized-Fuel Ash for use with Portland cement Part-1. London (1993).

(13) TSI. TS EN450-1-Fly ash for concrete - definitions, requirement and quality control. Ankara (1998) (in Turkish).

(14) European Standard. EN 450 - Fly Ash for Concrete - definitions, requirement and quality control, Brussels (1994).

(15) TSI. TS 706-Aggregates for Concrete. Ankara (1980) (in Turkish).

(16) J. G. Cabrera, and C. D. Atis: Design and properties of high volume fly ash high-performance concrete. Proceedings of ACI International Conference on High Performance Concrete and Performance and Quality Control Structures, SP-186, Gramado, RS, Brasil (1999), pp.21-37.

(17) ASTM. C-684-Standard Methods of Making, Accelerated Curing, and testing Concrete Compression Tests Specimens. Annual Book of ASTM Standard (1995).

(18) TSI. TS 3323-The Method of Making Accelerated Curing and Testing of Concrete Compression Test Specimens. Ankara (1979) (in Turkish).

(19) A. M. Neville, Properties of Concrete, p.844, $4^{\text {th }}$ Edition, Longman Group UK Limited (1995).

(20) P. K. Mehta. Concrete: Structure, Properties, and Materials. p.450, Prentice-Hall, Inc., Englewood Cliffs, New Jersey (1986).

(21) S. Popovics. Concrete materials: properties, specifications, and testing. p.661, $2^{\text {nd }}$ ed. New Jersey: Noyes Pubs. (1992).

(22) Postacýoðlu, B. Concrete. p.404, Press Technicians Pubs., Istanbul (1986) (in Turkish).

(23) M. Tokyay: Strength prediction of fly ash concretes by accelerated testing. Cement and Concrete Research, Vol.29, No.11 (1999), pp.1737-1741.

\section{NOTA:}

El Comité de Redacción de la Revista agradece al Dr. Moisés Frias la revisión técnica de la versión española del manuscrito. 